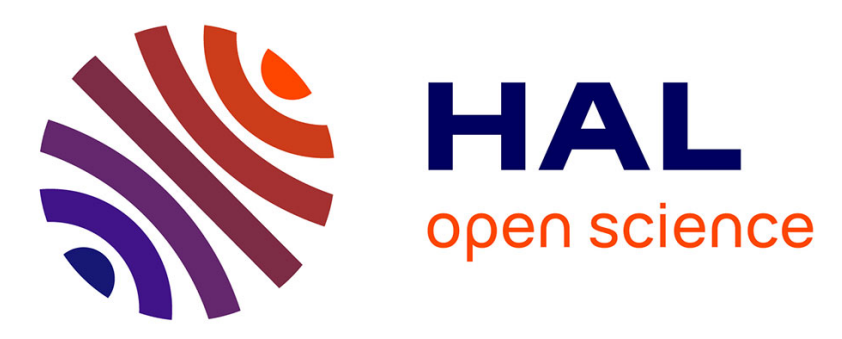

\title{
Riccardia verticillata Gradst. \& Reeb, a new dendroid species of Riccardia (Aneuraceae) from the Cordillera del Cóndor, Ecuador
}

S. Robbert Gradstein, Catherine Reeb, Claes Persson, Nicolás Zapata, Álvaro J Pérez

\section{To cite this version:}

S. Robbert Gradstein, Catherine Reeb, Claes Persson, Nicolás Zapata, Álvaro J Pérez. Riccardia verticillata Gradst. \& Reeb, a new dendroid species of Riccardia (Aneuraceae) from the Cordillera del Cóndor, Ecuador. Journal of Bryology, 2019, 41 (4), pp.322-327. 10.1080/03736687.2019.1681218. hal-02964197

\section{HAL Id: hal-02964197 https://hal.sorbonne-universite.fr/hal-02964197}

Submitted on 12 Oct 2020

HAL is a multi-disciplinary open access archive for the deposit and dissemination of scientific research documents, whether they are published or not. The documents may come from teaching and research institutions in France or abroad, or from public or private research centers.
L'archive ouverte pluridisciplinaire HAL, est destinée au dépôt et à la diffusion de documents scientifiques de niveau recherche, publiés ou non, émanant des établissements d'enseignement et de recherche français ou étrangers, des laboratoires publics ou privés. 


\section{A new dendroid species of Riccardia (Aneuraceae) from the Cordillera del Cóndor, Ecuador}

S. Robbert Gradstein ${ }^{\mathrm{a}}$, Catherine Reeb ${ }^{\mathrm{a}}$, Claes Persson ${ }^{\mathrm{b}}$, Nicolás Zapata ${ }^{\mathrm{c}}$ and Álvaro J. Pérez ${ }^{\mathrm{c}}$

a Muséum National d'Histoire Naturelle - Sorbonne Universités, Institut de Systématique, Évolution, Biodiversité (UMR 7205, CNRS , EPHE), BP 39, 57 rue Cuvier, 75005 Paris, France; 'bepartment of Biological and Environmental Sciences, University of Gothenburg, P. O. Box 461, 40530 Göteborg, Sweden; 'Herbario QCA, Escuela de Ciencias Biológicas, Pontificia Universidad Católica del Ecuador, Apartado 17-01-2184, Quito, Ecuador

CONTACT: S. Robbert Gradstein. E-mail: robbert.gradstein@mnhn.fr 


\begin{abstract}
Introduction. The Cordillera del Cóndor at the border of Ecuador and Peru stands out by its rich biodiversity and high endemism. Here we describe a new dendroid species of the thalloid liverwort genus Riccardia, R. verticillata Gradst. \& Reeb, from El Quimi Biological Reserve in the Cóndor region of Ecuador.
\end{abstract}

Methods. The plants were described using anatomical and morphological methods. For anatomical study, plants were treated with bleach (20\%) and colored with methylene blue, enhancing observation of the thallus structure.

Key results. The plants consist of a stout, erect axis with a subepidermis and regularly spatiated, horizontally spreading and flattened, densely 4-6-pinnate fronds, which are arranged in whorls. The axis and primary branches are wingless, the younger branches are broadly winged. An erect axis with a subepidermis and winged branches are also seen in the neotropical $R$. aberrans, $R$. ciliolata, $R$. fucoidea, $R$. gradsteinii, $R$. pallida, $R$. poeppigiana and $R$. wallisii, but these species are less densely pinnate and the branches are not arranged in horizontally spreading, flattened whorls, and are mostly fully winged, also the primary ones. In its verticillate habit, the new species is similar only to members of $R$. subg. Arconeura, including $R$. prehensilis from Tierra del Fuego and R. eriocaula from Australasia, but the latter taxa clearly differ in the papilliform epidermis cells and absence of thallus wings. A key to dendroid neotropical species of Riccardia is provided.

Conclusions. Riccardia verticillata stands out among neotropical Riccardia species by its markedly whorled habit. The discovery of the new species adds a further endemic taxon to the Cóndor region.

\title{
Keywords
}


Andes; Liverworts; Riccardia subg. Arconeura; Riccardia fucoidea; Riccardia verticillata;

Taxonomy 


\section{Introduction}

The Cordillera del Cóndor region is an eastern extension of the Andean chain, ranging about $150 \mathrm{~km}$ from north to south along the border between Ecuador and Peru. The mountains are mainly built of sandstone sediments and resemble the table mountains ('tepuis') of the Guiana Shield of Venezuela (Neill 2005). The sandstone-derived soils are highly acidic and nutrientpoor, and as a result the vegetation is typically sclerophyllous. Humic acids dissolved in the water draining from the sandstone substrate induce the characteristic blackish coloration of the rivers originating from the Cóndor region ('blackwater rivers'). Biological explorations in the Cordillera del Cóndor have revealed a very rich biodiversity and high endemism, and a large number of taxa shared with the tepuis of the Guiana Shield (Schulenberg and Awbrey 1997; Neill 2005, 2007). The bryophyte flora of the Cóndor region is little known, however. A first list by Churchill et al. (2009) reported 162 species, including 111 species of mosses, 50 of liverworts and one hornwort. A few additional liverwort species were recorded by Gradstein and Benitez (2014a, 2014b, 2014c). Most of the bryophyte species are widely distributed in the Andes but three taxa are hitherto only known from the Cóndor region, the moss Sphagnum algentryi H. Crum and the liverworts Bazzania hookeri (Lindenb.) Trevis. var. mamillosa (Gradst. \& A.R.Benitez) Gradst. \& A.R.Benitez and Syzygiella ciliata Gradst. \& A.R.Benitez. The liverwort Micropterygium duidae Reimers is only known from the Cóndor region and the Guiana Shield (Gradstein and Benitez 2014a).

One of the highest plateaus in Cordillera del Cóndor is El Quimi Biological Reserve, a protected area of 9276 hectares in the southeast of the province of Morona-Santiago, near the border with Peru. The area rises to $2000-2200 \mathrm{~m}$ and is covered by evergreen montane forests with a highly diverse flora, which is still poorly studied (Ministerio del Ambiente de Ecuador 2013). Characteristic tree species are Magnolia lozanoi A.Vázquez \& Castro-Arce, Lissocarpa ronliesneri B.Walln., Purdiaea nutans Planch., Drymis granadensis L.f., 
Weinmannia condorensis Z.S.Rogers and various species of Schefflera J.R.Forst. \& G.Forst. and Clusia L., whereas shrubs and herbs include, e.g., Miconia machinazana C.Ulloa \& D.A.Neill, Burmeistera sp. nov., Stenospermation arborescens Madison and many species of Bromeliaceae. Tree ferns are common and diverse, especially species of Cyathea J.E.Smith, whereas bryophytes are highly abundant and are fully covering the ground, tree trunks and branches. Unfortunately, El Quimi Biological Reserve and its surrounding areas face serious conservation problems due to open pit copper mine operations, the 'Mirador project', which has already caused deforestation of an area of about 1300 hectares (Mazabanda et al. 2018).

A major biological exploration of the El Quimi Reserve took place between July 2017 and April 2018 as part of the 'Arca de Noe' project funded by the Ecuadorian government, with the aim of characterizing Ecuador's biodiversity on a large scale (e.g., Ron et al. 2018). In this framework, botanical fieldwork was carried out in January 2019 lead by botanists of the Pontificia Universidad Católica del Ecuador (Herbarium QCA) with support of the University of Götebörg (Herbarium GB). Among the important findings were the re-collection of Magnolia lozanoi and the discovery of new species of Burmeistera H.Karst. \& Triana (Campanulaceae) and Riccardia Gray (Aneuraceae). The latter new species is described in this paper.

Neotropical species of Riccardia were recently studied by Gradstein and Reeb (2018) who recognised 14 species in Ecuador. Among them, the new species stands out by its whorled, dendroid habit, with regularly spatiated, horizontally spreading, flattened fronds on a stout, erect axis. The discovery of the new species adds a further endemic taxon to the Cóndor region.

\section{Material and Methods}


Material of the new species, collected by CP, NZ and AJP during the 2019 botanical exploration of the El Quimi Reserve, was studied by SRG and CR using traditional anatomical and morphological methods (e.g., Rabeau et al. 2017; Gradstein and Reeb 2018). For anatomical study, plants were treated with bleach (20\%) and colored with methylene blue, enhancing observation of the thallus structure (Rico 2011; Reeb and Bardat 2014).

Microscopic examinations and measurements were done with Leica DMLS light microscope; photomicrographs were taken with a Nikon CoolPix P5000 camera and post-processed with GIMP 2.8 (http://gimp.org). Voucher specimens are deposited in PC and QCA.

\section{Taxonomy}

Riccardia verticillata Gradst. \& Reeb sp. nov.

(Figures 1-3)

Diagnosis. The new species stands out by: 1) habit markedly verticillate, of a stout, erect axis bearing whorls of regularly spatiated, horizontally spreading, flattened, densely 3-5-pinnate fronds; 2) axis 30-40 cells thick along the smallest diameter, smooth, wingless; 3) fronds wingless below, broadly winged in the middle and upper parts, wings on ultimate branches 2 $4 \times$ broader than the midrib, margins crenate to obtusely toothed to incised-lobed, wing cells large, $50-80 \times 30-50 \mu \mathrm{m}$, arranged in oblique rows.

Holotype. Ecuador: Morona-Santiago, cantón Gualaquiza, parroquia Bomboiza, Reserva Biológica El Quimi, 'sendero entre el campamento Río Cristalino y la frontera con Perú, sector El Laberinto,' on wet, shaded soil covered by abundant organic matter in hyper-humid conditions, 03³1'05"S, 78²3'28"W, 1900-2200 m, 23 January 2019, N. Zapata, A.J. Pérez, W. Santillán \& C. Persson 541 (QCA; isotype PC).

Plants dendroid, to $10 \mathrm{~cm}$ tall, 4-6-pinnate and markedly verticillate, made up of a stout, erect, blackish axis bearing glossy-green, whorled fronds, the fronds regularly spatiated, horizontally spreading, flattened and densely 3-5-pinnate; main axis and basal parts of the 
fronds wingless, middle and upper portions of the fronds with broad, unistratose wings and darker-coloured midribs; surface of main axis and fronds smooth; stolons absent. Main axis rigid and somewhat flattened, bi-convex to ellipsoid, to $1 \mathrm{~mm}$ high and $1.7 \mathrm{~mm}$ wide, in cross section minimally 30-40 cells thick (along the smallest diameter), with a dark brown, thinwalled epidermis, a 2-3(-4)-layered, brown subepidermis and a colourless, thin-walled medulla, epidermal cells about as large as subepidermal cells and smaller than medullary cells, subepidermal cells slightly thick-walled in the upper part of the main axis (Figure 3I) and strongly thick-walled in the middle and lower parts (Figure 3H). Primary branches subopposite, spreading at wide angles of $60-80^{\circ}$ with the axis, wingless, resembling the main axis but slightly thinner and more conspicuously flattened (Figure 3G). Younger branches obliquely spreading, with unistratose wings and thin midribs, wings broadening towards ultimate branches, $0-2(-3)$ cells wide in the middle of the fronds, $4-8$ cells wide on ultimate branches, $2-4 \times$ wider than the midrib, margins of ultimate branches irregularly crenate to obtusely toothed to incised-lobed, apex truncate to emarginate on young ultimate branches, irregularly rounded to acute on older ones; midrib of ultimate branches 2-3(-5) cells wide, epidermal cells of the midrib in optical view subrectangular, 20-30 $\mu \mathrm{m}$ wide, thin-walled, ventral surface of ultimate branches with brownish papillae in two rows, bordering the midrib; wing cells of ultimate branches with brownish pigmented walls and distinct trigones, much larger than midrib cells, innermost wing cells $60-80 \times 40-50 \mu \mathrm{m}$, in a straight row parallel to the midrib, mid-wing cells slightly smaller, $50-75 \times 30-45 \mu \mathrm{m}$, in oblique rows at an angle of ca. $30-50^{\circ}$ with the midrib, margin cells somewhat smaller, protruding, forming an obscure border. Gametangia and asexual reproductive organs not observed.

Etymology. The specific epithet refers to the whorled habit of the species.

Paratype. The same as the type locality, A.J. Pérez, N. Zapata, W. Santillán \& C. Persson 11388 (QCA, PC). 
Distribution and habitat. Riccardia verticillata is thus far only known from El Quimi Biological Reserve in the Cordillera del Cóndor region, Ecuador (Morona Santiago province). The species grows between 1900-2200 m in hyper-humid, shaded conditions on wet soil covered by abundant organic matter. Populations were seen along a blackwater stream and at the entrance of 'El Laberinto', a sandstone outcrop with cracks covered by vegetation. In the latter site (type locality), $R$. verticillata was growing abundantly on soil constantly wetted by water dripping down from the vegetation on the top of the cracks.

\section{Discussion}

Riccardia verticillata is readily recognised by its dendroid, whorled habit, consisting of a stout, erect, wingless axis with a subepidermis and whorls of regularly spatiated, horizontally spreading and flattened, densely 3-5-pinnate fronds. The branches of well-developed fronds are broadly winged in the middle and upper parts of the frond while being wingless in the lower part, on the primary and secondary branches (Figure 3A). A dendroid habit, an erect main axis with a subepidermis, and winged branches are seen in several neotropical Riccardia species, including R. aberrans Steph., $R$. ciliolata (Spruce) Gradst., $R$. fucoidea (Sw.) C.Massal., R. pallida (Spruce) Meenks \& C.De Jong (? = R. glaziovii (Spruce) Meenks; see Gradstein and Reeb 2018), R. poeppigiana ((Lehm. \& Lindenb.) Meenks \& C.De Jong and $R$. wallisii (Steph.) Gradst. All are widespread in the Andes, from Colombia to Bolivia, and $R$. fucoidea occurs throughout the mountains of tropical America. The thallus branches in these species, however, are never arranged in horizontally spreading whorls. Moreover, most of them have a winged main axis, except $R$. poeppigiana and most populations of $R$. fucoidea. The latter of the two shares broad branch wings and large wing cells with $R$. verticillata and seems most closely related to the new species. Riccardia fucoidea, however, lacks horizontally spreading whorls and has a thinner axis (maximally 25 cells thick) with stolons at 
the base, winged primary branches and fully thin-walled wing cells in straight rows, parallel to the margin, without trigones (Gradstein and Reeb 2018). Moreover, R. fucoidea is 2-4pinnate while $R$. verticillata is 4-6-pinnate. The differences between the dendroid neotropical species of Riccardia are shown in the below key.

Pócs (2019) recently described an interesting new dendroid Riccardia species from Peru, R. gradsteinii Pócs, related to $R$. fucoidea but with a much thicker axis, to 40 cells thick. In the massive axis $R$. gradsteinii is similar to $R$. verticillata, but $R$. gradsteinii clearly differs in the main axis with strongly crispate wings and winged primary branches. Moreover, the branches in $R$. gradsteinii are not arranged in horizontally spreading whorls.

Within the genus Riccardia, a verticillate habit with horizontally spreading whorls is seen in R. prehensilis (Hook. f. \& Tayl.) C.Massal. from Tierra del Fuego and R. eriocaula (Hook.) Besch. \& C.Massal. from Australia and New Zealand (e.g., Hewson 1970; Hässel de Menendez 1972). The branches in these two species are wingless (R. prehensilis) or very narrowly winged (R. eriocaula), however, and the surface of axis and branches is strongly roughened by papilliform epidermal cells without chlorophyll. Based on the peculiar epidermis, these two species are placed in a separate subgenus, $R$. subg. Arconeura Hässel (Hässel de Menendez 1972). Riccardia verticillata and the other dendroid neotropical Riccardia species lack papilliform epidermal cells and are not members of subg. Arconeura. In a preliminary molecular analysis of the genus Riccardia at world level, Rabeau et al. (2017) recovered four dendroid neotropical species, $R$. ciliolata, fucoidea, $R$. pallida and $R$. wallisii, in a clade together with further species from the Andes, the socalled 'Andean clade'. The relationships of this clade, including its affinity to subg. Arconeura, were unresolved in the analysis, however, and need further study. Such a study should preferably include the newly described $R$. verticillata and $R$. gradsteinii, as well as the remaining dendroid neotropical taxa. 


\section{Key to dendroid neotropical species of Riccardia}

1. Thallus cells densely covered by lamellate papillae

R. aberrans

1. Thallus cells smooth 2

2. Main axis winged 3

2. Main axis not winged 7

3. Wing of main axis strongly crispate. Only known from Peru R. gradsteinii

3. Wing of main axis not crispate 4

4. Wings with ciliate teeth, the teeth 1-5 cell long, consisting of elongate cells. Branches short and plump, obliquely spreading. R. ciliolata

4. Wings entire or with short teeth, the teeth $0.5-1$ cell long, consisting of one subquadrate cell. Branches long and slender or short and plump, obliquely to widely spreading .... 5

5. Branches short and plump, suberect to obliquely spreading, not deflexed. Axis (0.8-)1-2 mm wide, plano-convex, gradually broadened toward the branch bases. Plants irregularly 1-2(-3)-pinnate R. wallisii

5. Branches long and slender (linear to subulate), obliquely to widely spreading, often deflexed. Axis less than $1 \mathrm{~mm}$ wide, bi-convex to rounded, not gradually broadened toward the branch bases. Plants \pm regularly 2-4-pinnate

6. Wing cells large, 35-50 $\mu$ m wide. All branches broadly winged. Wings of ultimate branches wider than the midrib R. fucoidea 
6. Wing cells smaller, 20-30(-35) $\mu$ m wide. Primary branches narrowly and interruptedly winged. Wings of ultimate branches narrower than the midrib R. pallida

7. Plants 4-6-pinnate, with regularly spaced whorls of horizontally spreading, flattened fronds. Primary branches wingless. Wings of ultimate branches $2-4 \times$ wider than the midrib, wing cells in oblique rows, with trigones. Only known from the Cordillera del Cóndor, Ecuador. R. verticillata

7. Plants 2-4-pinnate, without whorls of horizontally spreading fronds. Primary branches winged or wingless. Wings of ultimate branches narrower or wider than the midrib, wing cells in straight rows, without trigones. Throughout neotropical mountains 8

8. Wing cells large, 35-50 $\mu \mathrm{m}$ wide. Branches straight, not gradually narrowed to the apex. All branches regularly and broadly winged R. fucoidea

8. Wing cells smaller, 15-30(-35) $\mu$ m wide. Branches usually decurved, gradually narrowed to the apex. Ultimate branches winged but primary branches \pm without wing

R. poeppigiana 


\section{Acknowledgments}

Fieldwork was granted by the Ministry of the Environment of Ecuador (003-2019-IC-FLODNB/MAE). AJP, NZ and CP express their gratitude to Wilson Paucar (director of El Quimi Reserve), Juan Carlos Fernández (park ranger of El Quimi Reserve) and the Valle del Quimi community for their support during the field work, and the Secretaría de Educación Superior, Ciencia, Tecnología e Innovación de la República del Ecuador for financial support (SENESCYT, Arca de Noé Initiative, S. R. Ron and O. Torres-Carvajal, Principal Investigators).

\section{Notes on contributors}

Robbert Gradstein works at National Museum of Natural History of Paris as a research associate. His research interests include taxonomy and biogeography, especially of liverworts, and flora and vegetation of the tropics including human impact on biodiversity.

Catherine Reeb is a researcher at the Muséum National d'Histoire Naturelle of Paris and teaches biology, ecology and evolution at Sorbonne Université. Her research interest is integrative taxonomy, using molecular methods and morphometrics, with a taxonomic focus on thalloid liverworts. She is also engaged in the enhancement of knowledge of the bryophytes of Madagascar.

Claes Persson is lecturer in botany at the University of Gothenburg, Sweden and director of Herbarium GB. His research interest focuses on systematics of the coffee family (Rubiaceae) in the Neotropics, as well as taxonomy and floristics of Ecuadorian vascular plants. 
Nicolás Zapata is an undergrad student at the Biology School of Pontificia Universidad Católica del Ecuador. He has collaborated with the QCA herbarium for more than four years. His research interest is the systematics of lycophytes and ferns.

Álvaro Pérez works as a professor at the Biology School of Pontificia Universidad Católica del Ecuador and is the angiosperm curator of Herbarium QCA. His research interest includes the taxonomy and conservation of the Ecuadorian flora. 


\section{References}

Gradstein SR, Benitez A. 2014a. Micropterygium duidae Reimers. Journal of Bryology. $36: 142$.

Gradstein SR, Benitez A. 2014b. A second locality for the critically endangered Colura irrorata (Lejeuneaceae) in the Ecuadorian Andes. Journal of Bryology. 36:151-155.

Gradstein SR, Benitez A. 2014c. Two new taxa of leafy liverworts (Marchantiophyta: Jungermanniidae) from Cerro Plateado, Cordillera del Cóndor, Ecuador. Nova Hedwigia. 99:111-118.

Gradstein SR, Reeb C. 2018. The genus Riccardia in Colombia and Ecuador. Cryptogamie, Bryologie. 39:515-540.

Hässel de Menendez GG. 1972. Revisión taxonómica del genero Riccardia (Hepaticae). Revista del Museo Argentino de Ciencias Naturales "Bernardino Rivadavia", Botánica. 4, $1: 1-242$.

Hewson H. 1970. The family Aneuraceae in Australia and New Guinea. II. The genus Riccardia. Proceedings of the Linnean Society of New South Wales. 95:60-121.

Mazabanda C, Kemper R, Thieme A, Hettler B, Finer M. 2018. Impacts of mining project 'Mirador' in the Ecuadorian Amazon. https://maaproject.org/mirador-ecuador/

Ministerio del Ambiente del Ecuador 2013. Sistema de clasificación de los ecosistemas del Ecuador Continental. Quito: Subsecretaría de Patrimonio Natural.

Neill DA. 2005. Cordillera del Cóndor: Botanical treasures between the Andes and the Amazon. Plant Talk. 41:17-21.

Neill DA. 2007. Botanical exploration of the Cordillera del Cóndor region of Ecuador and Peru: Project activities and scientific findings, 2004-2007. http://www.mobot.org/MoBoT/Research/ecuador/cordillera/pdf 
Pócs T. 2019. New liverworts from the Peruvian Andes, II. Zoopsidella grahamii

(Lepidoziaceae) and Riccardia gradsteinii (Aneuraceae). Acta Botanica Hungarica. 61 (in press).

Rabeau L, Nebel M, Dubuisson JY, Krause C, Gradstein R, Quandt D, Reeb C. 2017. New insights into the phylogeny and relationships among the worldwide genus Riccardia (Aneuraceae, Marchantiidae). European Journal of Taxonomy. 273:1-26.

Reeb C, Bardat J. 2014. Studies on African Riccardia types and related material. Cryptogamie, Bryologie. 35:47-75.

Rico R. 2011. Methods for cell clearing and rehydration in thalloid liverworts. Tropical Bryology. 33:12-18.

Ron SR, Caminer MA, Varea-Jaramillo A, Almeida-Reinoso D. 2018. A new treefrog from Cordillera del Cóndor with comments on the biogeographic affinity between Cordillera del Cóndor and the Guianan Tepuis. ZooKeys. 809:97-124.

Schulenberg TS, Awbrey K. 1997. The Cordillera del Cóndor region of Ecuador and Peru: A biological assessment. RAP Working Papers. 7:1-231. 
(legends)

Figure 1. Population of Riccardia verticillata Gradst. \& Reeb.

Figure 2. Habit of Riccardia verticillata Gradst. \& Reeb.

Figure 3. Riccardia verticillata Gradst. \& Reeb. (A) Habit, rehydrated. (B) Young ultimate branches, with apical cells still actively dividing. (C) Mature ultimate branches. (D) Portion of ultimate branch in ventral view, showing papillae in two rows, bordering the midrib. (E) Wing cells of ultimate branch, showing trigones. (F) Cross sections of main axis, mid-portion. (G) Cross section of primary branch. (H) Cross section of part of mature main axis, showing subepidermal cells with strongly thickened walls. (I) Cross section of part of young main axis, showing subepidermal cells with slightly thickened walls s. (J) Cross sections of ultimate branches. Drawn from the holotype. Scale bars: $1 \mathrm{~mm}$ for (A); $250 \mu \mathrm{m}$ for (B, C, J); $50 \mu \mathrm{m}$ for (D, E); $500 \mu \mathrm{m}$ for (F, G); $100 \mu \mathrm{m}$ for (H, I). 


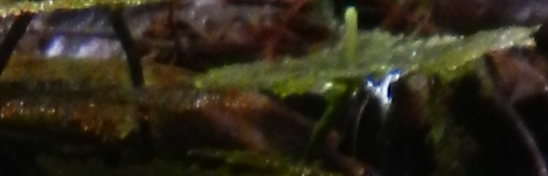

48

45

$4 \operatorname{los}^{3}$

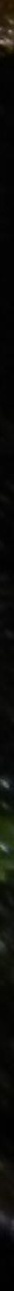

arest

as

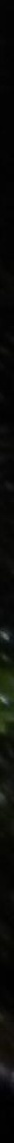

$x^{4}+x^{2}+2$

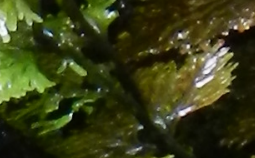

$-4$

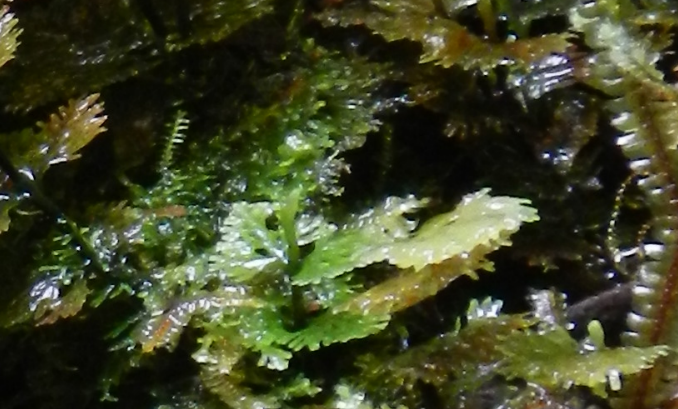
Enis
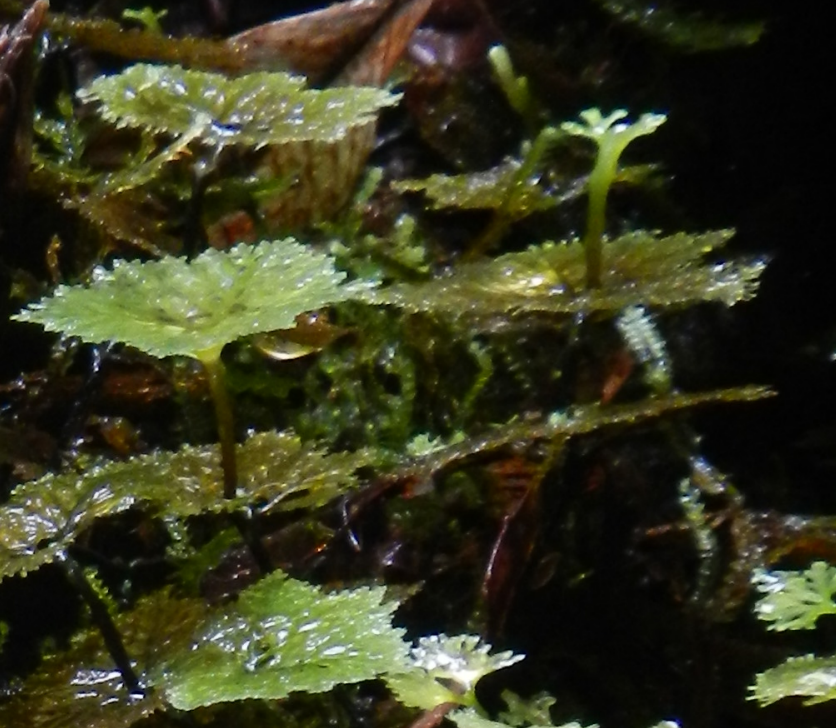

12

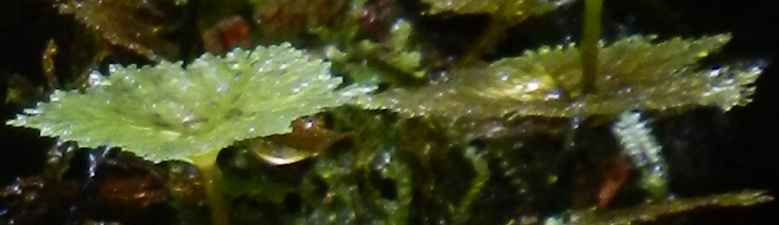

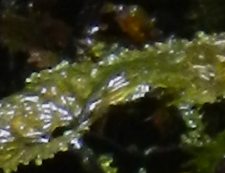

ws n w w Disying

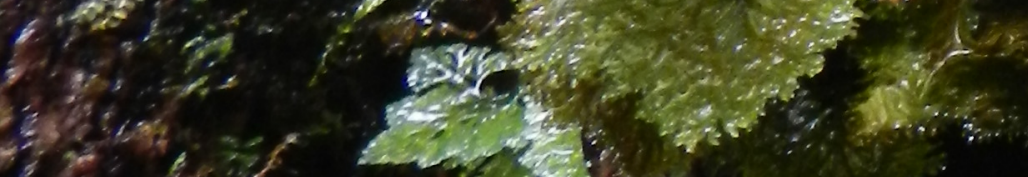




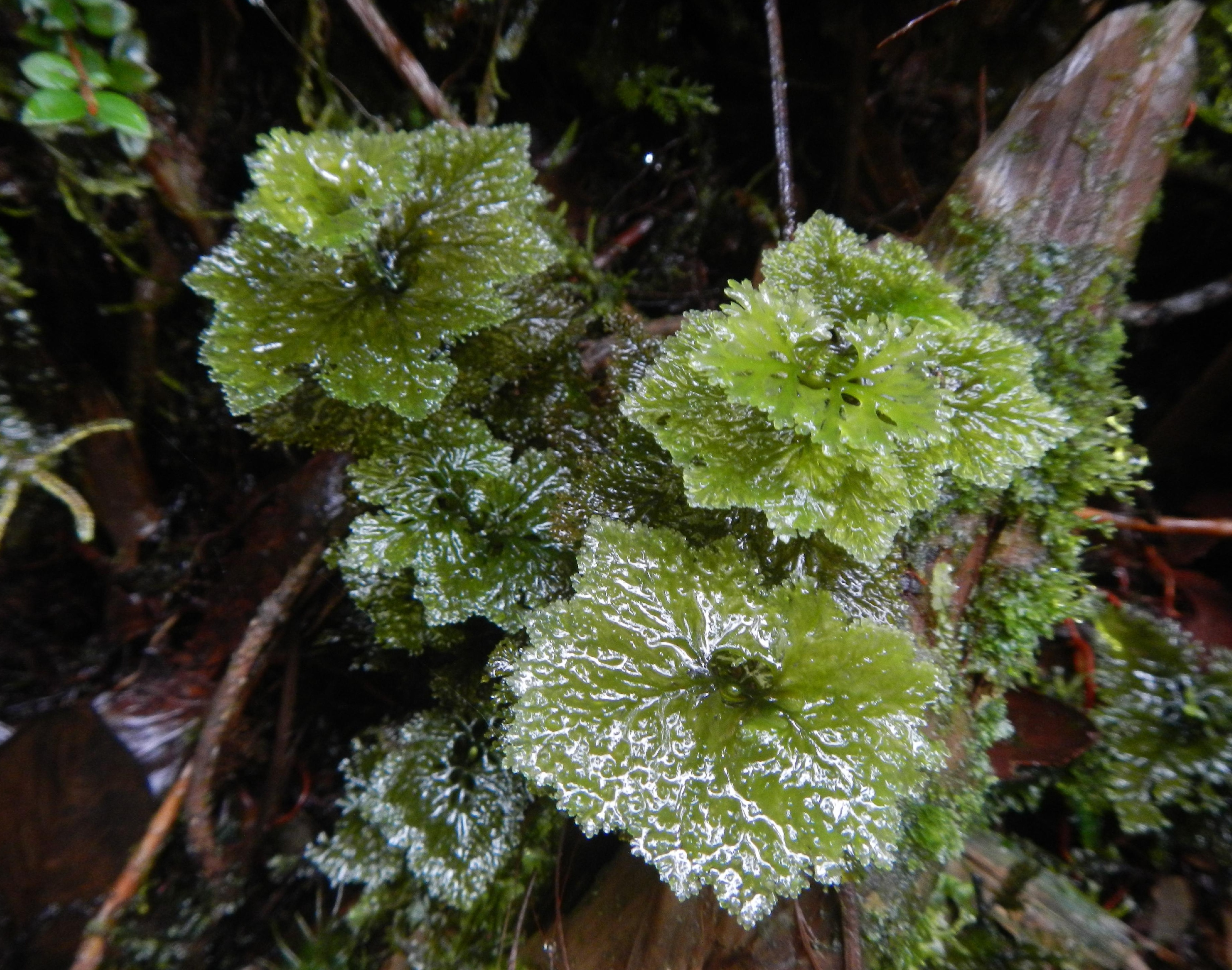




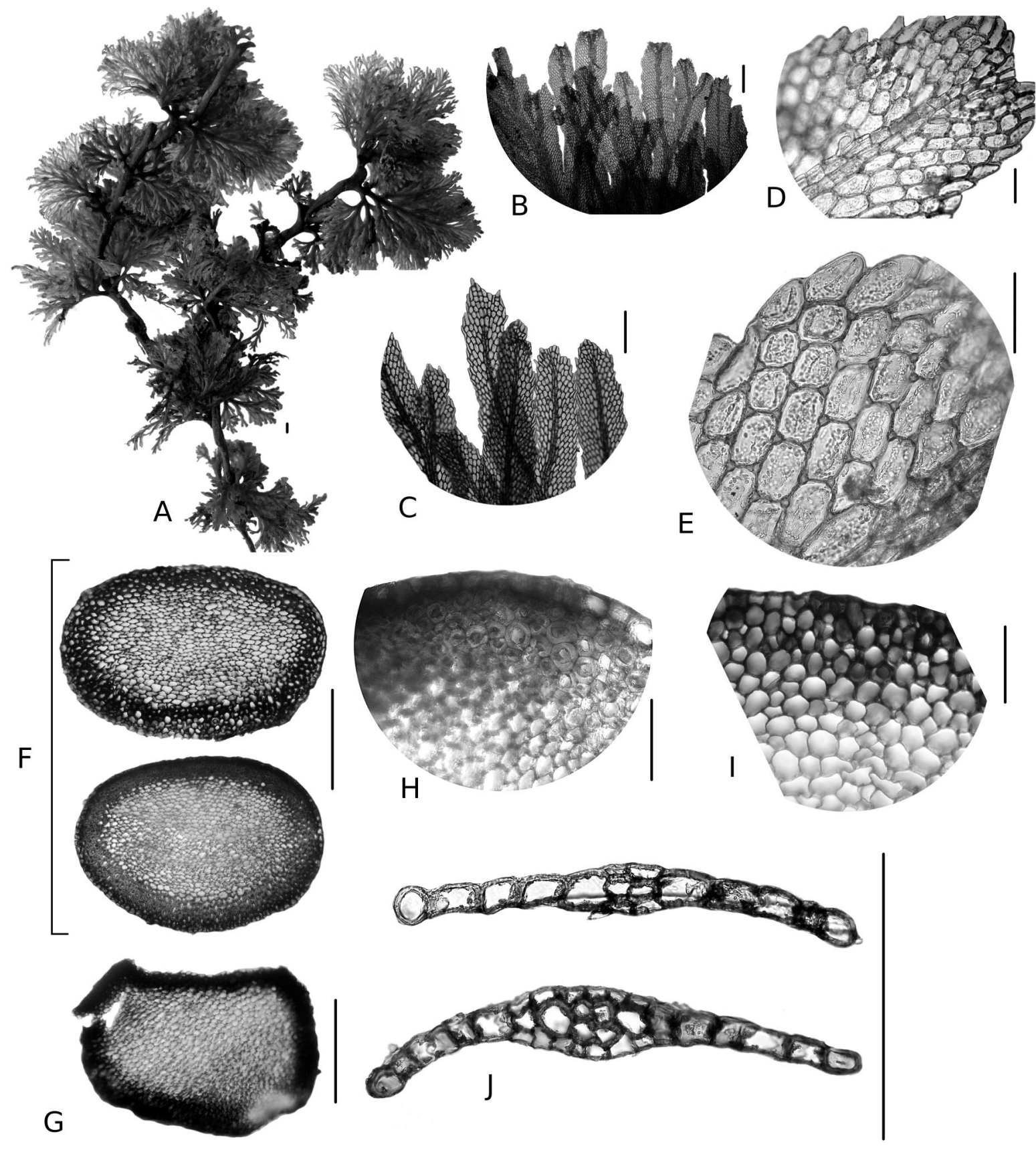

